\title{
Learning Networks in Innovation Systems at Sector / Regional Level in Argentina:Winery and Dairy Industries
}

\author{
Guillermo Sanchez', Roberto Bisang ${ }^{2}$
}

\begin{abstract}
This work studies how the set of relationships that gives place to the learning processes is established in the food industry in Argentina. A theoretical ad hoc approach is adopted, conjugating the concepts of innovation systems at sector / regional level with some context considerations like the innovative behaviour of the global and local food industry and a description of the public and private S\&T in Argentina. The study is focused in two cases: the wine industry, at the Mendoza province, and the dairy products industry at the centre of the Santa Fe province, both in Argentina. While the winery industry at the province of Mendoza exports differentiated products the dairy industry, at the central basin of the province of Santa Fe, exports commodities leaving differentiated (functional) products for the domestic market. These facts determine different dynamics between them, despite of what the established set of relationships is very complex and knowledge intensive in both cases. Also, in both cases the preponderant contribution of the public institutions of science and technology as knowledge and technology source is flagged.
\end{abstract}

Keywords: Argentina; innovation systems; learning network; food industry; winery industry; dairy industry; Mendoza; Santa Fe.

\footnotetext{
*Work supported by INTA (Res. Nr. 8I8/05) and CONICET (Grant Nr. I I 420090 I00025).

' Centro de Estudios Urbanos y Regionales, CONICET. Saavedra I5, 6to. Piso, CI083ACA, Ciudad Autónoma de Buenos Aires, Argentina. E-mail:gsanchez@conicet.gov.ar (corresponding author). Coordinación Nacional de Vinculación Tecnológica, INTA. Rivadavia I479, I A, Ciudad Autónoma de Buenos Aires,Argentina. E-mail: gsanchez@cnia.inta.gov.ar

${ }^{2}$ Consultant E-mail: robertobisang@gmail.com
} 


\section{Introduction}

In the frame of the evolutionary theory, since the works of Joseph Schumpeter, the innovation was identified as ubiquitous to the economy arising from the learning processes developed searching new products, techniques, ways of organization and markets. In this way, learning processes were identified as the suitable tool in order to build endogenous capabilities by incorporating knowledge to the goods and services production (Schumpeter, 1976).

Innovation systems are conceptualized as a set of relationships established in the innovative context to carry out learning processes. Usually innovation systems are studied as a national aggregated but it is, also, of particular interest an approach at the sub national level of sector and region. This disaggregated analysis is particularly relevant in the case of developing countries with their economies composed by a high participation of industries from the agri-food sector in their GDP.

In this work an approach at level of sector / regional innovation system is proposed. The set of relationships that arises to give place the learning processes in the innovation systems is considered to explore how public and private R\&D participates in such processes. The study is focused on two cases. One of them is that of the wine industry, at the Mendoza province, and the other is that of the dairy products industry at the centre of the Santa Fe province, both in Argentina.

In the next section some theoretical considerations that sustain the analysis are briefly pointed out. In the two following sections each one of the mentioned cases are presented. Finally, some general considerations are presented in the last section closing it with some conclusions.

\section{Some considerations about theory}

From the perspective of the evolutionary economic theory, economic development is a process that involves the co-evolution of technologies -known and in use, and the institution supporting and regulating them. What the term 'institution' means is a central point of this theoretical body. The innovation system strand of research combines under that term two overlapped ideas. First, the complexity of many market relationships embedded in broader social and institutional structures, and the elements of cooperation and trust. Second, the role of non-market institutions, like university and public research systems, scientific and technical societies, government programs in the innovation process in many sectors. Thus, institutions encloses those involved in the early stages of the innovation process, particularly devoted to research and development (R\&D), the labour market, the education system, financial institutions, regulatory structures, and other institutions that shape economic dynamics more broadly (Nelson, 2007a).

Nelson and Sampat (Nelson and Sampat, 200I cited in Nelson, 2007b) go ahead unpacking the concept of institution. They define the concept of social technologies differentiating technical steps e.g., steps in a receipt -named as physical technologies, from the way those steps are applied -social technology. Thus, industrial R\&D can be viewed as a combination of a set of physical technologies -e.g., lab procedure, and social technologies -e.g., a division of labour among scientists and various structures of coordination and direction. According to this approach the focus is on the prevalent social technology being eclectic about what institution is. In this way institution can be a lot of things that support social technologies and, also, constrain them (Nelson, 2007b).

The Nelson's approach pointed out previously is convergent with the socio-technical approach from the sociological studies of technology. This can be understood in terms of the technological systems approached by Thomas Hughes (1987, cited in Versino, 2006). Technological systems can be defined by their objectives -e.g., to solve problems, and by their components-complex, diverse and heterogeneous, coordinated in terms of problem - solution. According to Hughes op. cit. the system components can be physical artefacts, organizations -e.g., enterprises, banks, etc., scientific elements -e.g., books, articles, teaching and research programs, etc., laws, regulations, patents, etc. Through their interactions, those components contribute to reach the system objective and due to those interactions the action of any of the component impact in that of the other ones. Also if one of the components is changed or modified the performance of the system is also affected (Versino, 2006). In this way, similarly as was indicated by Nelson (2007a), a co-evolution of the entire system exists.

There are some contact points between both, Nelson and 
sociological approaches. They are coincident in the sense that behind the innovation process there is somewhat social that constrain and mould the prevalent technology and that is supported by somewhat eclectic that we can call "institutions". Also they are in agreement with the systemic behaviour in order to build sustainable capabilities for innovation. Finally, they are coincident in viewing the learning processes as the most relevant tool to a successful sociological, technical and economic performance.

From the perspective of that strand of research, the innovation systems is viewed as the set of relationships established in order to carry out the learning processes over a wide variety of aspects -scientific, technological, organizational, normative, etc. Learning can be understood as a process of development of new knowledge-increasing the stock of knowledge, a process of recombination of existing knowledge, or a process of acquisition of existing knowledge by new people. However, the last two are more valuated considering that the economic, social and technical changes arising from the continuous transformation and destruction of specialized knowledge are potentially more effective and sustainable for a successful economic performance than the simplest fact of increase the knowledge stock.

In the literature there are several studies about learning process and knowledge. Nonakca and Takeuchi (1999) present the learning process as a continuous transformation between tacit and codified knowledge in a spiralled loop through four steps (socialization - exteriorization combination - internalization) repeated cyclically. Others approaches consider learning by repetition, feedback, and investigating or learning by doing, using and interacting (Johnson, 1992). For knowledge categories, in the literature it can be found know how; know what; know why; know who. Johnson (1992) refers to learning by exploring for knowledge obtained through basic research at public scientific labs -scientific knowledge and to learning by research for knowledge obtained through the research at industries R\&D labs -technological knowledge.

\section{Innovation in the food industry}

The innovative behaviour is quite similar for the whole global food and beverage industry. On one hand, following the Pavitt taxonomy (1984) the innovative process in this industry can be classified as driven by suppliers. This means that the innovations are dependent of innovations in others industries (chemical, biotech, metal mechanics, additives, ingredients, and equipment).

On the other hand there are some intrinsic constrains to the technological change in this industry arising from three kinds of issues. The first one is the biological base of the production. The industrial process is strongly dependent of volume and quality of raw material produced by agriculture and, thus, it is conditioned by biological processes, more or less, out of control'. The second issue is that associated to the human consumption of food products. As the products are addressed to human consumption, both products and production processes, are subject of strict norms and regulations in order to ensure their safety and nutritional quality. Furthermore, the food industry must take in consideration both consumer concerns (sometimes aversion) about processing technology, animal welfare, etc. and consumer cultures, religions, habits, tendencies, etc. The third issue is related to product itself. One of them is in terms of the short life cycle of the products due to an increasing strategy of competitiveness between firms through the portfolio diversification (non-price competitiveness). The other one is related to the limited shelf life of both processed and fresh products what encourage to improve technology in logistic, preservation, conditioning, packaging, etc. (Bisang and Gutman, 2005).

In the particular case of Argentine food industry there are some specific constrains due to its heterogeneity. In the country, it is possible to identify sub systems of production very dynamics technologically that operate at the international border pulled by the foreign markets. Other sub systems oriented to the domestic market

\footnotetext{
1 This impact s doing production processes extended in time, reducing (in comparison with other industrial activities) the rate of capital rotation in addition to the economic risk by the occurrence of climatic events.
} 
both, with a strong product differentiation and products without differentiation addressed to massive consumption. Furthermore, regional sub systems, technologically behind those, with products addressed to local consumption -even at the subsistence level, with poor national projection are found. In the Argentine case, also should be pointed out the concentration process since the $90 \mathrm{~s}$ where transnational firms began to participate in the domestic market, accomplished by the consolidation of big national firms and groups, the joint venture between national and transnational firms and the elimination of enterprises of small and medium size (Gutman and Cesa, 2004). Such heterogeneity is also expressed at the level of the endogenous capabilities suitable for the development, adaptation, adoption and diffusion of technology. Following the dynamic previously described, transnational and big national firms of the food industry have incorporated R\&D department as their own source of knowledge and technology. In the opposite side, there is a universe of small and medium sized firms that are extremely dependent on external source of knowledge and technology. This dependence will be strongly accented as the sub system dynamics decreases.

Thus in the case of the Argentine food and beverage industry intrinsic constrains to the technological change and sub national heterogeneity are combined to constitute an important bottle necks for the accumulation of social actives. The innovation system at the level of sub national sector and region is a useful approach in order to understand the dynamics and to find ways for solves such bottle necks (Christensen, Rama and von Tunzelmann., 1996).

\section{Public and private R\&D in Argentina}

Following the post II World War wave of institutionalization of science started in the USA and the allied countries, the backbone of the institutional configuration regarding public R\&D in Argentina was completed at the middle of the $X X$ century. During the ' 50 s the four mean institutions devoted to R\&D were founded: in 1950 the National Commission for Atomic Energy - CNEA ${ }^{2}$, in 1956 the National Institute of Agricultural Technology -INTA ${ }^{3}$, in 1957 the National Institute of Industrial Technology $-|N T|^{4}$ and in 1958 the National Council for Scientific and Techniques Research -CONICET ${ }^{5}$. These institutions completed the body of public R\&D with the Universities that started during the XIX century.

Such body has evolved since those until these days, being its actual composition difficult of enumerate completely. To the mentioned institutions, of national scope, others ones were summed in time with a wide diversity of concerns and geographic scope due to the diversity of districts that pursuit the incorporation of science and technology -S\&T, to their policies.

According to indicators, published by the National Statistic System on Science and Technology, for the year 2007 the public S\&T accounted for 38 thousand people between researchers and postgraduate students (fellowship). For the same year, the expenditure in R\&D reached the $0.51 \%$ of the GDP while in scientific and technological activities -as defined by UNESCO, reached $0.6 \%$ of the GDP. In both cases $65 \%$ of the effort corresponded to the public sector and the remaining $35 \%$ to the private one (MinCyT, 2008).

Such data can be understood by the fact that R\&D in enterprises is an activity carried out only by transnational firms and by a short number of big national firms or groups operating in the country. However, transnational firms have their R\&D labs in their central houses located, in general, in developed countries. Developments in such labs are bringing to the local subsidiaries protected through patents and other tools of intellectual property protection. In this way such capabilities are out of the

\footnotetext{
' Comisión Nacional de Energía Atómica, the Spanish name. Support of science and technology to policies in matter of nuclear energy for the peace. http://www.cnea.gov.ar

${ }^{2}$ Instituto Nacional de Tecnología Agropecuaria, the Spanish name. Support of science and technology for agriculture and animal production. http://www.inta.gov.ar/

${ }^{3}$ Instituto Nacional de Tecnología Industrial, the Spanish name. support of science and technology to the manufacturing industry. http:// www.inti.gov.ar

${ }^{4}$ Consejo Nacional de Investigaciones Científicas y Técnicas, the Spanish name. It is the main government organization devoted to the promotion science and technology in Argentina. Its activities involve four knowledge areas:Agriculture, Engineering and Materials, Biologic and Health sciences, Exacts and Natural Sciences and Social and Humanistic sciences. http://www.conicet.gov.ar/
} 
national frontier having scarce (or neither) impact on the building of national endogenous capabilities. The big core of the local industries is composed by small and medium enterprises without capacity to generate their own R\&D being, thus, necessary to be supported by public capabilities of R\&D.

By these days there are two current relevant issues in the public agenda regarding policy in S\&T. One of them it is to find out a high level of coordination between the several S\&T institutions in order to achieve a real systemic behavior in the institutional body. It was pointed out by scholars on S\&T policy that, in Argentina, the S\&T constitutes a complex rather than a system due to the poor (or inexistent) coordination in the actions of the several components. The other relevant issue is to match S\&T priorities to those of production in order to incorporate knowledge as a strategic input in productive processes. In the current situation a tension demand-pull / offer-push is observed in the harmonization between S\&T priorities and production requirements. This dichotomy leaves far away a desirable systemic behaviour in order to achieve an effective knowledge based productive system.

\section{Methodology}

According to that exposed previously, the way to explore learning networks associated to productive subsystems in agri-food could be following the set of relationships achieved to that end. In the literature it can be found a wide number of conceptual and methodological approaches for to do that -e.g. the Actor-Network Theory (ANT) (Latour, 2005; Harty, 2010). Networks, also can be viewed as organizational forms adopted by firms in order to minimize costs (Bisnag and Gutman, 2005).

In this work, relationships are explored through public information and by interviewing qualified referents. The set of relationships thus obtained was reproduced as an adjacency matrix according to the Social Network Method (Hanneman and Riddle, 2005), and plotted using the package UCINET 6 (Borgatti, Everett and Freeman, 2002). As result, a map of the relationships is obtained for every studied case. Such maps are analyzed taking in mind the Functional Model of Innovation Systems (FMIS) by Kadura, Langbein and Wilde (20II). The present study can be framed by the micro level of the FMIS being the maps expressions of a particular set of linkage at such level. The observed type of actors and type of the established connection let to identify some of the bridging institutions presented in each case.

\section{The winery industry at the Mendoza province, Argentina}

The winery provinces in Argentina are those in the western of the country. From the north to south, on the Andes mountain chain: Salta, Catamarca, La Rioja, San Juan, Mendoza, Neuquén and Río Negro. The province of Mendoza, Argentina, is located at the middle west of the country, on the base of the Andes. Together with the provinces of San Juan and San Luis, Mendoza constitutes the geographic region known as Cuyo.

Since the begging of the productive activity, at the end of the XIX century, several changes were operated in the production system as responses to changes in consumption and destination markets and to techniques troubles. Such changes can be described grouping them in technical, organizational and juridical issues.

Technical issues involve the whole chain of production. Varieties, ways of growing, irrigation methods, plague controls are the most relevant ones operated at level of primary production. In the wine industrialization it can be mentioned the first challenge due the climate situation in order to solve the high temperatures during the grape collecting process which summed to the low acidity and the high sugar levels of grape, delayed or retard the fermentation process. Later other technological changes like the use of stainless steel, refrigeration systems and new packaging systems were occurring during the time until the last decade of ' 90 . These changes represented investments in expensive devices, incorporating, advances in microelectronics, automatic control, and software, between others. In correlation with this, according to the complexity of the new technology, specialized professionals in a wide spectrum of fields were demanded.

Organizational issues includes from the original division between who growth grape and who transform it in wine passing to industries that also growth grape and to the grouping under gremials organization, cooperatives, and others of producers, industriesandworkers. Alsotherecent advances on quality management and quality certification systems should be considered within these issues. Juridical issues include a big number of laws that were establishing the rules for wine production during the time. 
In 1959, the General Law of Wines $N^{\circ} 14.878$ founded the National Institute of Grape and Wine Growth, INV. The Institute was created in order to promote the economic activity of the sector, to control its products and to carry out, to promote and to coordinate research applied to grape and wine production. Later the scope of the INV was changing in the time. First, in 1991 in the frame of the deregulation of the economy (Law $\mathrm{N}^{\circ}$ 24.307), the concerns of the INV was limited to the control of authenticity of products. Later, in 1996 the National Law of Alcohols $\mathrm{N}^{\circ} 24.566$ is promulgated and the INV is committed as application authority of the norm controlling the production, circulation and trading of ethylic and methyl alcohols. In 1999 by Law 25.163, the INV is committed as administrative and technical support of the origin denomination system for wine and spirituous drink of wine origin. Also represents Argentina in the Wine International Organization, in the Wine Trading Group and in the MERCOSUR.

The National State promoted the strategic planning for the sector through the Law 25.849 creating the Argentine Corporation of Viticulture, COVIAR, as the executor of the plan. The Corporation is a public-private entity, understood as a tool of management sustained by the common good ${ }^{6}$. This is the way in which the Argentine viticulture has chosen to be organized (COVIAR, 2004).

The conformation of COVIAR as it was established by the law, including the main actors of the sector innovation system, could be assumed as an organizational issue (COVIAR 2004). However there are four groups, relevant for such system not considered by the law. Those are the equipments, inputs, ingredients, etc., suppliers; professional formation and education centres (Universities and education institutions); research institutes on behalf of INTI and CONICET; and social organizations devoted to development and integration of territory. However, during the elaboration of the Strategic Plan Viticultural Argentina 2020 -with the acronyms PEVI 2020 or just
PEVI, were incorporated new institutions to the process. Such is the institutional context in which de PEVI was built under the leadership of INTA. The preliminary step previous to the PEVI elaboration was an analysis of strength, opportunity, weakness and threat. Analyzing the conclusions of such study it is possible to understand some aspects of the dynamics of the innovative process. Strengths and opportunities, related to the market and the demand, the presence of others comparative advantages and some virtuous actors from the point of view of the innovative process were identified. The most relevant bottle neck identified by the actors was the severe weakness on R\&D, considering it as the engine of the innovative process, and the organizational weakness (Ruiz and Vitale, 20II).

\section{The dairy industry at the centre of the Santa Fe province, Argentina}

The diary industry of Argentina is of oligopoly type with the presence of a small group of big companies -national and transnational, rounded by a big group of small and medium enterprises. After years of oriented to the domestic market, during the 90 s this sector suffered the economy deregulation, adapting it to the market requirements passing, then, by international and local crisis. These events were reflected in the sector by recurrent cyclic crises driven the technology path dependence (Bisang et al., 2008; Gutman, Guiguet and Rebolini, 2003, Gutman, 2007).

The province of Santa $\mathrm{Fe}$ is located at centre eastern of the country within the papeana plain, in the core of the richest productive area of the country. Following official data from the government published at the web site www. santafe.gov.ar, in 2005 this province contributed $36 \%$ of national milk production, more than 3,300 million litters, from around 3,700 dairy farms, approximately $29 \%$ of the total establishments nationwide. In the province

\footnotetext{
${ }^{6} \mathrm{As}$ it is established by the law, the COVIAR is integrated by: Argentine Viticulture Cooperatives Association, Mendoza Viticulturalists Association, Wineries of Argentina, Argentine Chamber of Must Manufacturers and Exporters, San Juan Chamber of Wine-producers, San Juan Chamber of Viticulture Producers, Riojana Chamber of Agricultural Producers, San Juan Chamber of Viticulture, Eastern Viticulturalists and Wine-producers Centre, Federation of Argentine Viticulture Chambers, Province of Mendoza Government, Province of San Juan Government, Province of La Rioja Government, Province of Salta Government, Province of Catamarca Government, Province of Neuquén Government, Province of Río Negro Government, National Agricultural Technology Institute (INTA), National Viticulture Institute (INV), Dessert grapes and Raisins Producers, Argentine Viticulture Union.
} 
there are 181 industrial plants, belonging to 156 dairy companies that process raw materials from their own province and neighbouring provinces, Cordoba and Santiago del Estero. Over $\mathbf{8 0 \%}$ of the raw material for the manufacture of cheese and milk powder, slightly more than $9 \%$ for fluid milk and the rest to yoghurt and other products. Of all dairy companies mentioned, 25 have products of international transit and other goods have federal or provincial transit.

Milk production in the province of Santa Fe can be grouped in three areas-North, Central and South, with the central basin -Departments Castellanos, Las Colonias and Capital, the most important by the number of facilities that account ( 2522 a total of 4477 ) and its production volume ${ }^{7}$.

In terms of processes, innovations have occurred with different intensity, depending upon the size of the company. The largest ones resort on the importation of turnkey plants or main equipment. As the size of the company is reduced, it begins to appear local suppliers of equipment. First, as a mix of national and transnational suppliers for the case of medium to small companies and then as sole national suppliers in the case of small to micro enterprises. While larger companies acquire, in this way, technology near the international border, the smaller just make adjustments in the technologies they had dominated for several years (Mateos, 2006).

Firms in this subsystem, located in the central basin of the province of Santa Fe, cover the entire spectrum of sizes of industries and primary production establishments. In a general observation, the pattern of technological behaviour of these actors matches the one described above, as has been discussed in detail in the literature (Gutman, Guiguet and Rebolini, 2003; Gutman, 2007; Bisang et al. 2008).

From the information collected from qualified informants in the region, some of the general features mentioned above are verified: i) the main sources of knowledge are the providers of goods and inputs, there are some isolated virtuosos cases who gain knowledge from public $R \& D$; ii) higher $R$ \& $D$ efforts are made by larger companies, inhouse, by having a $R$ \& $D$ or ad hoc teams to develop new products or through partnerships with public institutions, iii) the smaller companies have a more conservative style of production. They made only minor adjustments to their production processes, differentiate their products at the request of its customers or take advantage of sales opportunities through mature production processes and only ask help to public $R \& D$ to solve specific problems or for routine checks which capacity is not available in their quality control laboratories.

According to the obtained information, public R\&D that brings knowledge to the production of dairy subsystem of this basin consists of five major players. Four of them present in the region under study and the fifth located far away. They are: i) the Institute of Industrial Lactology -INLAIN, with shared dependence CONICET and National University of Litoral -UNL, through the School of Chemical Engineering, located in the city of Santa Fe; ii) the Institute of Food Technology, under the School of Chemical Engineering, UNL, located in the city of Santa Fe, ITA-UNL; iii) INTI - Lácteos, devoted to dairy production, based in the city of Rafaela, iv) INTA, through the EEA Rafaela based in the city of Rafaela, v) the Reference Centre for Lactobacillus-CERELA, with shared dependence between the CONICET and the National University of Tucuman, UNT, located in the city of San Miguel de Tucumán, province of Tucumán.

\section{Concluding remarks: The observed learning dynamics}

In the previous sections it was traced how it is built the knowledge network through learning processes associated with Local / Sector Innovation Systems, by articulating production and S\&T public institutions. Several types of linkage were observed in the studied cases.

Regarding the case of the wine industry at the Mendoza province, one type of connection is that established due to COVIAR between the constituent actors according to the law. Others type of links are those due to PEVI elaboration and COVIAR Programs execution. Others connections are related to INTA due to agreements of cooperation, technology transfer and the execution of the winery regional project. Other connections are product

\footnotetext{
${ }^{7}$ According to data of 2004 , in this basin, major dairies in the country are present, most of which have features multiplant.
} 
of financing S\&T activities and linking of technology suppliers. Finally, non connected institutions of S\&T are detected (see Figure I and Annex I for used acronyms).

The set of relationships described for the winery industry enclose learning processes in several fields. This agroindustsrial sector has improved its competitiveness introducing technical and organizational changes according to market requirements. The elaboration of the strategic plan and the COVIAR creation are indicators of consensus arrived about the actions to be executed. Between them, the necessity of to build an innovation process with the participation S\&T institution is flagged. On one hand, the identification of which are such S\&T institutions it is pendent. On the other one, it is necessary to sensitize and to involve S\&T institution different from INTA that are present at the region but with poor reflexivity in the productive sector.

In the case of the dairy industry at the central basin of Santa Fe province the type of the established connection are due to source or demand of technology, the execution of INTA Regional Project, offer of education, grants for S\&T activities and the embryonic coordination role by the strategic plan of province of Santa Fe (Santa Fe, 2009) (see Figure 2 and Annex I for used acronyms). 


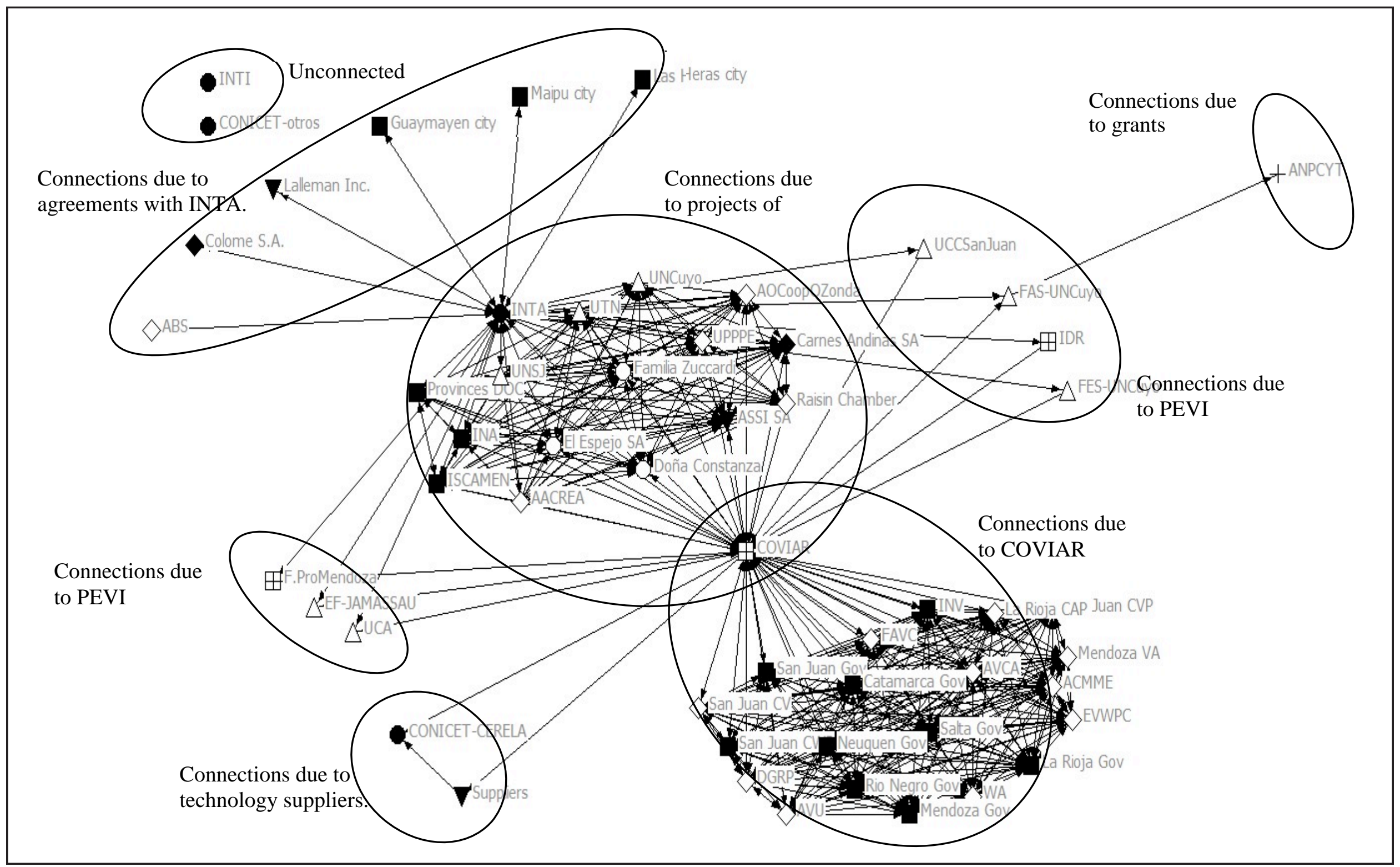

Figure I: Set of relationships established in the case of the winery industry at the province of Mendoza,Argentina. The type of the observed connections depends of the social matter that flows between actors. 


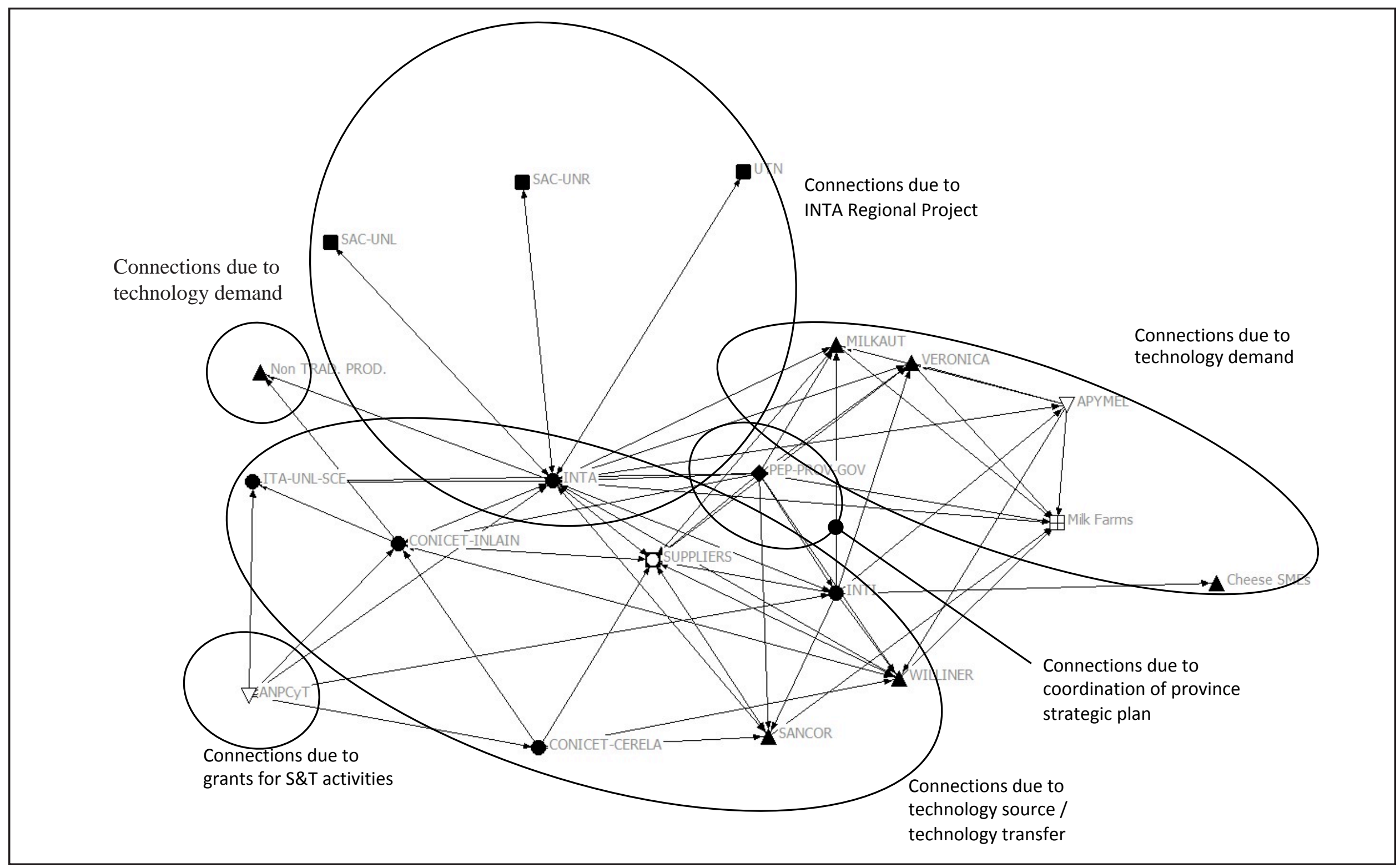

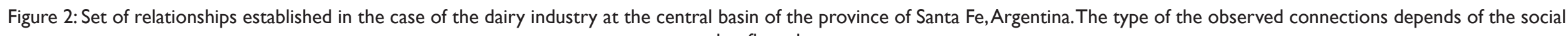
matter that flows between actors. 
Here a wide distribution of the work between public S\&T institutions was found. INTA combines its action through S\&T projects of national scope, under its National Milk Program and Food Technology Strategic Area, the implementation of regional projects, by the Regional Centre Santa $\mathrm{Fe}$ and their dependent units (INTA, 2005). This results in a large number of linkages with various institutions: research centres, universities (local and foreign) enterprises, farmers' associations and public bodies. Local agencies of CONICET, INTI and the UNL are part of this network in which INTA has the coordinating role and, moreover, each one of they develops its own network (not included in Figure 2). This results in a network of multiple connections between the actors where the knowledge flows in different directions. In order to simplify this description the main avenues through which knowledge circulates can be identified. In one of these avenues can be placed issues related to primary production and its impact on product quality, mainly cheese and powdered milk. Here the knowledge flow is through INTA in connection with producers and industries, mainly medium to large sized.

Other of the avenues is referred to processes and product quality of liquid and powdered milk and cheese. Here the knowledge is flowing through the INTI and INLAIN connecting industries and producers, mainly small and medium sized.

Finally the avenue devoted to lactic acid bacteria, probiotics, nutrition and new products development. Here the knowledge flows through CERELA, INLAIN and companies supplying inputs specialized in these industries, with R\&D departments or ad hoc teams for new products development. The flow of knowledge is largely connected to industries big sized of national origin.

The difference observed in aspect between both figures can be described in terms of the number of the involved actors and of the actor density. Nevertheless, these differences are neither cause nor consequence of the technological virtuosity of each industry itself. Such difference could be explained by the technological dynamics of each industry driven by the type of the traded product. While the wine industry mainly exports a differentiated product addressed to niches, the dairy industry exports commodities addressing differentiated products to the domestic market.
Type of actors can be grouped under different categories as it is shown in Figure 3 where a comparison between the distribution for of the studied cases it is presented. Associations it is referred to those constituted by enterprises of similar activity and characteristics, in general, in order to act as defender of the rights and interests of their members. The presence of a specific association brings, implicitly, the presence (or at least the agreement) of its members. Enterprises can be grouped as those of primary production (Primary), industry (Industry) and suppliers of devices and ingredients (Suppliers). Those actors which are or are part of National, Province and City governments are under the category Government Organizations. Universities and public institution of S\&T are considered categories apart from Gov. Org., even though both of them are government dependent. Those actors which are not part of government are grouped as Non Government Organizations. Finally there is a unique institution devoted to finance activity in S\&T, is the National Agency for Promotion of Scientific and Technological Activities, ANPCYT as Funds category. 
Winery and dairy industries. Type of inolved actors

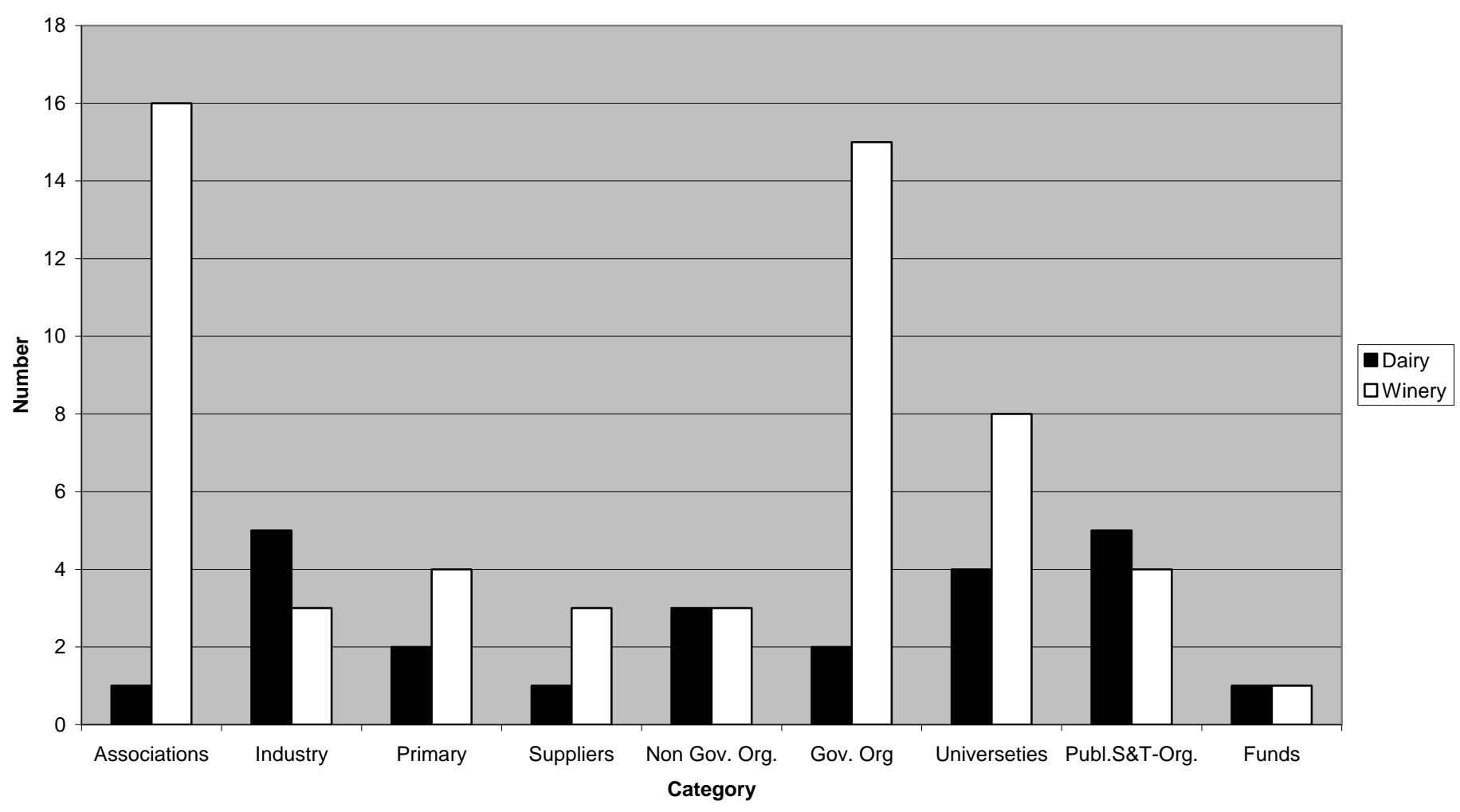

Figure 3: Type of involved actors: Associations: constituted by enterprises of similar activity and characteristics, in general, in order to act as defender of the rights and interests of their members. Enterprises: grouped as those of primary production (Primary), industry (Industry) and suppliers of devices and ingredients (Suppliers). Government Organizations (Gov. Org.): part of National, Province and City governments. Universities. Public Institutions of S\&T (Public-S\&T-Org.). Non Government Organizations (Non Gov. Org.). Funds: The unique institution devoted to finance S\&T activities, is the ANPCYT.

In terms of the FMIS (Kadura, Langbein and Wilde op. cit.) the set of relationships showed in Figure $I$ and 2 reflects the dynamic at micro level of the innovation system for the studied cases regarding learning process. In every case, the type of the observed connection identifies particular "bridging institutions". Other issues (like public policy, budget, educational system, etc.) could be analysed in deep from Figures I and 2 nevertheless, such analysis is out of the focus of this paper.

The strategic plans can be assumed like one of such bridging institutions. For the wine case the strategic planning is prompted by the national state but carried out by local actors. In the case of the central dairy basin of the province of Santa Fe this action is promoted from the provincial government and goes beyond the sector and the region under study integrating the entire province and all the problems.
In the case of wine at the province of Mendoza the planning action, from the way in which it was developed, can be interpreted as a kind of bottom-up initiative which gives more importance to social and economic forces for the creation of institutions over the role of the state (McDermott, 2007). Consequently, considering the history of the industry in that province, PEVI represents, in terms of flow of knowledge, a vehicle of that it was already circulating. It does not appear in the immediate future, to be a mediator of new fluxes or connections, giving visibility to other actors in the network or adding new players to it. Despite of this, some actors not included as member of COVIAR appeared as participants in implementing COVIAR programs -Faculty of Enology and Agribusiness Juan Agustín Maza University, Faculty of Agricultural Sciences, National University of Cuyo (that appears linked to INTA) and the Argentine Catholic University. 
Similarly it happens with potential actors identified in PEVI with participation in the implementation of strategic actions under the broad name of "S\&T organizations." From this group, INTA is the only actor who appears clearly differentiated. This validates its positive social reflectivity in actors of productive sector. While at the geographical area of production, there are units of INTI and CONICET that could inject knowledge into the network, according to their research lines, it has not traced the corresponding connections with them.

In opposition to that, it can be mentioned the reinforcing of existing connections, where COVIAR plays a crucial coordinating role. This it is shown through the "Program of Assistance for Argentine Viticultural Value Chain (Resolution Nr. 249/09) signed in the field of the Ministry of Agriculture, Livestock and Fisheries. The Program aims to improve the competitiveness of the sector, strengthening the turnover and value creation, employment genuine, and in particular to integrate small and medium producers and processing establishments to the wine value chain. Programme will be coordinated by the Undersecretary of Agribusiness \& Markets of the Ministry, and COVIAR. Among individual stocks in the area of the Programme is the strengthening of institutional coordination and support and advocacy for the adoption of new technologies and processes that contribute to the expansion of the wine sector.

As it was shown by the Strength - Weakness - Opportunity - Threat (SWOT) analysis conducted prior to the preparation of PEVI, Ferraro and Costamagna (2000) found, for the Santa Fe location, poor perception of the local R\&D and its impact on the innovative processes. However, from the presented information an interested cluster of connections between network actors -public institutions for S\&T, business, educational and social institutions, etc was observed.

In the studied cases, the relationship between the identified actors is conditioned by history and the success or failure of previous experiences. In the first successful experiences, the relationship occurs spontaneously. These successful experiences act as mediators to make the actors come and perform joint actions, both for the wine at Mendoza and the central milk basin of the province of Santa Fe cases.

\section{Acknowledgments}

Special thanks to Graciela Gutman, Mariana Versino, Pablo Lavarello, Sonia Filipetto and the whole CEUR's team by the constructive discussions and their rich contributions.

\section{References}

BISANG, R. and Gutman, G.E. (2005). Redes agroalimentarias y acumulación: reflexiones sobre la experiencia reciente en el MERCOSUR. En Casalet M. Cimoli M. y Yoguel G. (Eds.) Redes, Jerarquías y Dinámicas Productivas. Experiencias en Europa y América Latina. FLACSO, DF, México.

BISANG, R.; Porta; F.; Cesa; V.; Campi, M.; Fernandez Bugna, C. (2008) La cuestión distributiva en la trama láctea argentina: una aproximación al reparto del excedente de explotación. Documento de Proyecto. LC/W.I87- LC/ BUE/W.27. CEPAL, Santiago, Chile.

BORGATTI, S.P., Everett, M.G. and Freeman, L.C. 2002. Ucinet for Windows: Software for Social Network Analysis. Harvard, MA: Analytic Technologies.

CHRISTENSEN, J.L.; Rama, R.; von Tunzelmann, N. 1996. Study on innovation in the European food products and beverages industry. In: Industry studies of innovation using CIS data. The European Comission, Brusels.

COVIAR (2004). Plan Estratégico Argentina Vitivinícola (PEVI) 2020. www.vitivinicultura2020.com.ar [Accessed Febreury 6, 2009]

FERRARO, C; Costamagna, P. (2000) Entorno institucional y desarrollo productivo local. La importancia del ambiente y las instituciones para el desarrollo empresarial. El caso de Rafaela. CEPAL, Oficina Buenos Aires. LC/BUE/R.245

GUTMAN, G.E.; Guiguet, E.; Rebolini, J. (2003). Los ciclos en el complejo lácteo argentino. Análisis de políticas lecheras en países seleccionados. Secretaría de Agricultura, Ganadería, Pesca y Alimentos de la Nación. Mesa Nacional de Lechería. Programa Calidad de los Alimentos Argentinos. Proyecto ARG 96/006, Convenio PROSAP - BIRF ARG/96-6-8/00. www.minagri.gov.ar [Accessed Febreury 25, 20I0] 
GUTMAN, G.E. and Cesa, V. (2004). Innovación y cambio tecnológico en las industrias de la alimentación en argentina. En Bisang, Lugones y Yoguel (ed.) Apertura e innovación en argentina. Para desconcertar a Vernon, Shumpeter y Freeman. Ed. Miño y Avila, Redes, UNGS, Buenos Aires, Argentina.

GUTMAN, G.E. (2007) Ocupación y empleo en el complejo productivo lácteo en la Argentina. En Novick M, y Palomino H. (coords.) Estructura Productiva y empleo. Un enfoque transversal, Ministerio de Trabajo, Empleo y Seguridad Social, PP 225-268, Editorial Miño y Dávila. Buenos Aires, Argentina. ISBN 978-84-9657I-68-6.

HANNEMAN, R. A. and Riddle, M. (2005). Introduction to social network methods. Riverside, CA: University of California, Riverside (published in digital form at http:// faculty.ucr.edu/ hanneman/ ) [Accessed October 12, 2009]

HARTY, C. (2010) Implementing innovation: designers, users and actor-networks. Technology Analysis \& Strategic Management, 22: 3, 297 - 315

INTA (2005) "El INTA que queremos. Plan Estratégico Institucional 2005 - 2015". Buenos Aires, Argentina: Instituto Nacional de Tecnología Agropecuaria http:// wwwl.inta.gov.ar/pei/ [Accessed December 5, 2006]

JOHNSON, B. (1992) Institutional learning. In Lundvall (ed.) National Systems of Innovation. Towards a Theory of Innovation and Interactive Learning. Printer Publishers, London, UK.

KADURA, B.; Langbein, J. and Wilde, K. (20II) Strengthening Innovation Systems. Foundation, concept and strategic approach. Verlag Dr. Kovac, Hamburg, Germany.

LATOUR, B. (2005) Reassembling the social - An introduction to Actor - Network Theory. Oxford University Press, New York, USA. ISBN 978-987-500-114-5

MCDERMOTT, G. (2007). The Politics of Institutional Renovation and Economic Upgrading: Recombining the Vines That Bind in Argentina. Politics Society 2007; 35; 103
MATEOS, M (2006). La industria láctea: heterogeneidad estructural y comportamiento tecnológico. En Ghezán, Acuña, Mateos, (Eds.) Estrategia y dinámica de la innovación en la industria alimentaria argentina., 139 - 176. Astralib, Buenos Aires, Argentina. ISBN 987-1214-04-9

MinCyT. (2008). Indicadores de Ciencia y Tecnología. Argentina 2007. Ministerio de Ciencia, Tecnología e Innovación Productiva, Presidencia de la Nación. Ciudad Autónoma de Buenos Aires, Argentina. www.mincyt.gov.ar [Accessed March 13, 2010]

NELSON, R. (2007a) Economic Development from the Perspective of Evolutionary Economic Theory. The Global Network for Economics of Learning, Innovation, and Competence Building System (GLOBELICS). Working Papers Series No. 2007-02. ISBN: 978-970-70I-963-8 www.globelics.org [Accessed July 7, 2010]

NELSON, R. (2007b) Institutions, "Social Technologies", and Economic Progress. The Global Network for Economics of Learning, Innovation, and Competence Building System (GLOBELICS). Working Papers Series No. 2007-03. ISBN: 978-970701-963-8 www.globelics.org [Accessed July 7, 2010]

NONAKA, I.; Takeuchi, H. (1999) La organización creadora de conocimiento. Cómo las compañías japonesas crean la dinámica de la innovación. Oxoford University Press, México, DF. ISBN 9706134549

PAVITT, K (1984). Sectoral patterns of technical change: Towards a taxonomy and a theory. Research Policy 13 343-373

RUIZ, A.M. y Vitale, J.A. (20II) Prospectiva y Estrategia: El caso del Plan Estratégico Vitivinícola 2020 (PEVI). Estudios socioeconómicos de los sistemas agroalimentarios y agroindustriales, Nro. 7. Ediciones Instituto Nacional de Tecnología Agropecuaria, Buenos Aires, Argentina. ISSN 1852-4605

SANTA FE (2009) Plan Estratégico Provincial. Santa Fe Cinco regiones, una sola provincia. www.santafe.gov.ar [Accessed January, 30, 2009]

SCHUMPETER, J.A. (1976) Capitalism, Socialism and Democracy. Harper and Row, New York, USA. 
VERSINO, M.S. (2006) “Análise sócio-técnica de processos de produção de tecnologias intensivas em conhecimento em países subdesenvolvidos. A trajetória de uma empresa nuclear e espacial argentina (1970-2005)". Universidade Estadual de Campinas. Instituto de Geociências PósGraduação em Política Científica e Tecnológica. Tese apressentada ao Instituto de Geociências como parte dos requisitos para obtenção do título de Doutor em Política Científica e Tecnológica. Campinas, Brasil. http:// libdigi.unicamp.br/document/?code $=v t \mid s 000392993 \& \mathrm{fd}=\mathrm{y}$ [Accessed October I, 2009] 


\section{Annex I: Institutions acronyms used in figures I and 2}

\section{Figure I}

AACREA: Argentine Association of Regional Consortiums of Agriculture Experimentation

ABS: Winery Association of Salta

ACMME: Argentine Chamber of Must Manufacturers and Exporters

ANPCYT: National Agency of Science and Technology Promotion

AOCoopQZonda: Agroindustrial and Organic Cooperative Quebrada de Zonda

ASSI SA: Enterprise devoted to equipment manufacture

AVCA: Argentine Viticulture Cooperatives Association

AVU: Argentine Viticulture Union

Carnes Andinas SA: Enterprise

Catamarca Gov: Province of Catamarca Government

Colome S.A.: Enterprise

CONICET-CERELA: Reference Centre for Lactobacillus dependent of the National Council of Scientific and Technique

Research and the National University of Tucuman

CONICET-otros: Other institutes from CONICET

COVIAR: Argentine Corporation of Viticulture

DGRP: Dessert grapes and Raisins Producers

Doña Constanza: Enerprise

EF-JAMASSAU: Enology Faculty of Juan Agustin Massa University

El Espejo SA: Enterpise

EVWPC: Eastern Viticulturalists and Wine-producers Centre
F.ProMendoza: Foundation ProMendoza

Familia Zuccardi: Winnery

FAS-UNCuyo: Faculty of Agricultural Science of the National University of Cuyo

FAVC: Federation of Argentine Viticulture Chambers

FES-UNCuyo: Faculty of Economic Science of National University of Cuyo

Guaymayen city: Guaymayen city

IDR: Foundation of the Rural Development Institute

INA: National Institute of Water and Environment

INTA: National Agricultural Technology Institute

INTI: National Institute of Industrial Technology

INV: National Viticulture Institute

ISCAMEN: Mendoza Institute for Sanity and Quality

La Rioja CAP: Riojana Chamber of Agricultural Producers

La Rioja Gov: Province of La Rioja Government

Lalleman Inc.: Supplier Enterprise

Las Heras city: Las Heras city

Maipu city: Maipu city

Mendoza Gov: Province of Mendoza Government

Mendoza VA: Mendoza Viticulturalists Association

Neuquen Gov: Province of Neuquén Government

Provinces DOC: Provinces Direction of Contingency

Raisin Chamber: Raisin Chamber

Rio Negro Gov: Province of Río Negro Government

Salta Gov: Province of Salta Government 
San Juan CV: San Juan Chamber of Viticulture

San Juan CVP: San Juan Chamber of Viticulture Producers

San Juan CWP: San Juan Chamber of Wine-producers

San Juan Gov: Province of San Juan Government

Suppliers: Suppliers

UCA: Argentine Catholic University

UCCSanJuan: Catholic University of Cuyo at San Juan

UNCuyo: National University of Cuyo

UNSJ: National University of San Juan

UPPPE: Productive Unit Small Producers from east

UTN: Technological National University

WA: Wineries of Argentina

Figure 2

INTA: National Institute of Agricultural Technology

INTI: National Institute of Industrial Technology, agency devoted to dairy production

CONICET-INLAIN: Institute of Industrial Lactology dependent of the National Council of Scientific and Technique Research and National University of Litoral

CONICET-CERELA: Reference Centre for Lactobacillus dependent of the National Council of Scientific and Technique Research and the National University of Tucuman

ITA-UNL-SCE: Institute of Food Technology dependent of the Chemical Engineering Faculty of the National University of Litoral

UTN: National Technological University

SAC-UNL: Faculty of Agricultrual Science at the National University of Litoral
SAC-UNR: Faculty of Agricultural Science at the National University of Rosario

VERONICA: Cheese producer enterprise

WILLINER: Dairy industry

SANCOR: Dairy industry

MILKAUT: Dairy industry

PEP-PROV-GOV: Strategic plan of Santa Fe province government

SUPPLIERS: Suppliers enterprises

APYMEL: Small and Medium Dairy Enterprises Association

Milk Farms: Milk farms

ANPCyT: National Agency of Science and Technology Promotion

Cheese SMEs: Small and medium enterprises

Non TRAD. PROD: Non traditional producers of cheese 
J. Technol. Manag. Innov. 20II,Volume 6, Issue 4 